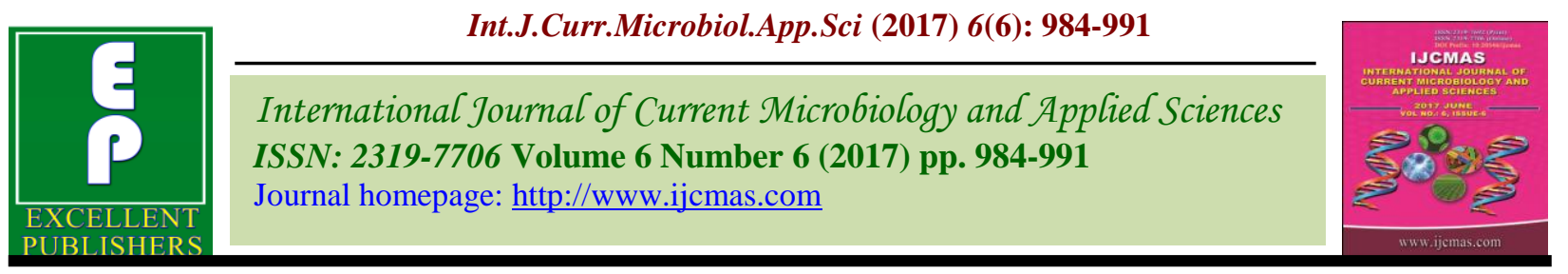

Original Research Article

https://doi.org/10.20546/ijcmas.2017.606.115

\title{
Effect of Different Level of N P K and Gypsum on Soil Properties and Yield of Groundnut (Arachis hypogaea L.) var. Jyoti
}

\section{Murli Dhar Bairagi*, Arun Alfred David, Tarence Thomas and Prakash Chand Gurjar}

Department of Soil Science and Agricultural Chemistry, Naini Agricultural Institute Sam Higginbottom University of Agriculture, Technology and Science Allahabad,

211007 (U.P.), India

*Corresponding author

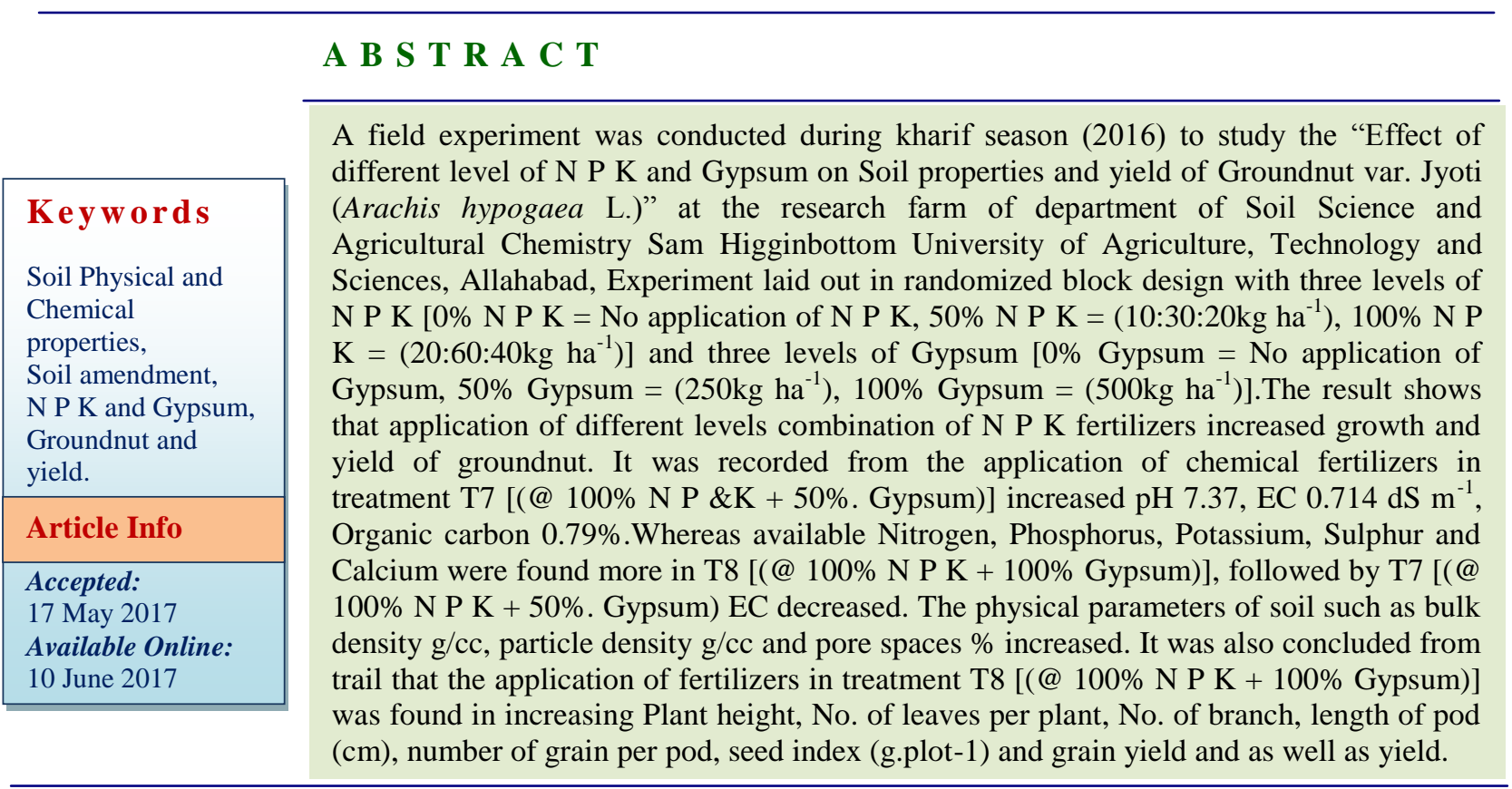

\section{Introduction}

Groundnut or peanut (Arachis hypogaea L.) which is also known as a 'King' of oilseed (Sathya et al., 2013) is a rainfed crop and grown in Kharif season Groundnut oil is edible oil and finds extensive use as a cooking medium both as refined oil and vegetable Ghee. Groundnut also has value as a rotation crop. Being a legume with root nodules, it can synthesize atmospheric nitrogen and therefore improve soil fertility. The residual oilcake contains $7-8 \% \mathrm{~N}, 1.5 \% \mathrm{P}_{2} \mathrm{O}_{5}$ and $1.2 \% \mathrm{~K}_{2} \mathrm{O}$ and is used as an organic fertilizer and it is also used for manufacturing artificial fibre. It is an important protein supplement in cattle and poultry rations. The haulms (plant stalks) are fed (green, dried or silage) to livestock. Groundnut shell is used as fuel for manufacturing coarse boards, cork substitutes etc. (Varghese, 2011). The optimization of the mineral nutrition is the key to optimize the production of groundnut, as it has very high nutrient requirement and the recently released high yielding groundnut varieties remove still more nutrients from the soil. On contrary 
groundnut farmers, most part of the semi-arid region use very less nutrient fertilizer and sometime only one or two nutrients resulting in severe mineral nutrient deficiencies due to inadequate and imbalance use of nutrients is one of the major factors responsible for low yield in groundnut. India is the world's largest producer of groundnut where nutritional disorders cause yield reduction from 30 to $70 \%$ depending upon the soil types. Thus it is high time to look into the mineral nutrition aspects of groundnut for achieving high yield and advocate the suitable package of practices for optimization of yield (Singh, 2004). Significant increase in pod yield of groundnut was observed at a fertilizer level of 30: 60:30 $\mathrm{kg} \mathrm{N} \mathrm{P} \mathrm{K} \mathrm{ha}{ }^{-1}$ and increase in yield was $30 \%$ higher than lower level of fertilizer doses (Kumar et al., 2000). In India, about $75 \%$ of the groundnut area lies in a low to moderate rainfall zone with a short period of distribution. It has been grown over an area of 5.31 million hectare and producing 6.93 million tones, of groundnut (DOAC, 2012) with productivity of $1305 \mathrm{~kg} \mathrm{ha}^{-1}$ in Indian context. Its cultivation is mostly confined to the states of Gujarat, Andhra Pradesh, Maharashtra, Tamil Nadu and Karnataka. The average area under groundnut cultivation in Junagad district during 2011 was 4.42 lakh hectares with production of 9.57 lakh tones and productivity of $2162 \mathrm{~kg} \mathrm{ha}^{-1}$ (DOAC, 2012).

Gypsum is widely used as a source of $\mathrm{Ca}$ for groundnut worldwide. Groundnut response to Gypsum as with any other fertilizer depends on the fertility status of the soil. The dissolution of Gypsum is fairly rapid and therefore readily adds $\mathrm{Ca}$ to the podding zone. However the major disadvantage of Gypsum is its vulnerability to leaching especially on light textured soils. Positive responses have been observed on sandy soils with $\mathrm{pH}$ less than $5.0\left(0.01 \mathrm{M} \mathrm{CaCl}_{2}\right)$. Survey data from the small holder farming sector has shown that the majority of the farmers do not apply
Gypsum or any other basal fertilizer to groundnut (Chikowo, 1998). The use of lime instead of Gypsum can provide not only $\mathrm{Ca}$ for the ground crop but also improves the availability of other plant nutrients. Proper incorporation of lime into the soil ensures the availability of $\mathrm{Ca}$ in the podding zone (Cox et al., 1982).

\section{Materials and Methods}

\section{Soil sampling}

The soil of experimental area falls in order of Inceptisol and in experimental plots is alluvial soil in nature. The soil samples randomly collect from five different sites in the experiment plot prior to tillage operation from a depth of $0-15 \mathrm{~cm}$. The size of the soil sample reduce by conning and quartering the composites soil sample is air dry and pass through a $2 \mathrm{~mm}$ sieve by way of preparing the sample for physical and chemical analysis. The experimental details are given below under different heading.

\section{Design and treatment}

The experiment was carried out in $3 \times 3$ factorial randomized block design with three levels of N P K, three levels of Gypsum. The treatments were replicated three times and were allocated at random in each replication.

\section{Experimental sites}

The experiment was conducted on the research farm of department of Soil Science and agricultural chemistry, Sam Higginbottom University of Agriculture, Technology and Sciences, Allahabad which situated six km away from Allahabad city on the right bank of yamuna river, the experimental site is located in the sub tropical region with $250 \mathrm{~N}$ latitude $81.500 \mathrm{E}$ longitude and 95 MS Laltitude. 


\section{Fertilizer application}

The fertilizers were applied in each plot according to treatment combinations. The nitrogen requirement meets with urea $46 \%$. The nitrogen was applied with the three different levels i.e.levels of N P K [0\% N P K $=$ No application of N P and K, 50\% N P K = $\left(10: 30: 20 \quad \mathrm{~kg} \mathrm{ha}^{-1}\right), \quad 100 \% \quad \mathrm{~N} \quad \mathrm{P} \quad \mathrm{K}=$ (20:60:40 $\left.\left.\mathrm{kg} \mathrm{ha}^{-1}\right)\right]$ and three levels of Gypsum $[0 \%$ Gypsum $=$ No application of Gypsum, $50 \%$ Gypsum $=\left(250 \mathrm{~kg} \mathrm{ha}^{-1}\right), 100 \%$ Gypsum $\left.=\left(500 \mathrm{~kg} \mathrm{ha}^{-1}\right)\right]$ was given in equal quantity to each plot which was calculated on the basis of general recommendation for maize as $0 \mathrm{~kg}, 80$ $\mathrm{kg}, 100 \mathrm{~kg} \mathrm{ha}^{-1}$ was supplied. On the basis of treatment combination the fertilizer used are described in table 1.

\section{Results and Discussion}

\section{Result of mechanical and chemical analysis of post-harvest composite soil samples}

Perusal of table reveals the maximum bulk density 1.18 was recorded with (N1G2) treatment combination followed by 1.13 with (N0G2) treatment whereas the minimum 1.02 bulk density was recorded with (N0G1) treatment. The statistical analysis of bulk density data indicates that there was significant difference in bulk density interaction between N P K and Gypsum. Similarly, the maximum Particle density 2.73 was recorded with (N1G2) treatment combination followed by 2.62 with (N0G2) treatment whereas the minimum 2.25 Particle density was recorded with control (NOG0) treatment. The statistical analysis of Particle density data indicates that there was significant difference in Particle density interaction between N P K and Gypsum. In the case of pore space the maximum pore space 50.98 was recorded with (N1G2) treatment combination followed by 50.00 with (NOG2) treatment combination whereas the minimum 47.05 pore space was recorded with control (NOG0) treatment. The statistical analysis of pore space data indicates that there was significant difference in pore space interaction between N P K and Gypsum. The maximum $\mathrm{pH} 7.37$ was recorded with (N1G2) treatment combination followed by 7.33 with (N2G0) treatment whereas the minimum 7.07 $\mathrm{pH}$ was recorded with control (NOG0) treatment. The statistical analysis of $\mathrm{pH}$ data indicates that there was non-significant difference in $\mathrm{pH}$ interaction between N P \& K and gypsum. The trend of EC the maximum EC dS m-1 7.14 was recorded with (N2G1) treatment combination followed by 7.33 with (N2G0) treatment whereas the minimum 6.94 EC was recorded with control (NOG0) non difference in EC interaction between N P K and gypsum. The result of the data depicted that the maximum organic carbon 0.82 was recorded with (N2G1) treatment combination followed by 0.74 with $(\mathrm{N} 2 \mathrm{G} 0)$ treatment whereas the minimum 0.61 organic carbon was recorded with control (NOG0) treatment. The statistical analysis of organic carbon data indicates that there was non-significant difference in organic carbon interaction between N P K and Gypsum. In case of available nitrogen the maximum available nitrogen 286.87 was recorded with (N2G2) treatment combination followed by 25.20 with $(\mathrm{N} 2 \mathrm{G} 0)$ treatment combination whereas the minimum 236.57 available nitrogen was recorded with control (NOG0) treatment. The statistical analysis of available nitrogen data indicates that there was significant difference in available nitrogen interaction between $\mathrm{N} \mathrm{P}$ $\mathrm{K}$ and Gypsum. The maximum available phosphorus 27.00 was recorded with (N2G2) treatment combination followed by 25.20 with $(\mathrm{N} 2 \mathrm{G} 0)$ treatment combination whereas the minimum 19.51 available phosphorus was recorded with control (NOG0) treatment. The statistical analysis of available phosphorus data indicates that there was significant difference in available phosphorus interaction 
between N P \& K and Gypsum. The maximum potassium 220.80 was recorded with (N2G2) treatment combination followed by 213.31with (N2G1) treatment combination whereas the minimum 127.24 potassium was recorded with control (N0G0) treatment (Table 2-5; Figs 1-3).

Table.1 Fertilizer and soil amendment treatment combination

\begin{tabular}{|c|c|}
\hline S. NO. & Symbol \\
\hline 01 & $\left(\mathbf{T}_{0}=\mathbf{N}_{0}+\mathbf{G}_{0}\right)$ \\
\hline 02 & $\left(\mathbf{T}_{1}=\mathbf{N}_{0}+\mathbf{G}_{1}\right)$ \\
\hline 03 & $\left(\mathbf{T}_{2}=\mathbf{N}_{0}+\mathbf{G}_{2}\right)$ \\
\hline 04 & $\left(\mathbf{T}_{3}=\mathbf{N}_{1}+\mathbf{G}_{0}\right)$ \\
\hline 05 & $\left(\mathbf{T}_{4}=\mathrm{N}_{1}+\mathrm{G}_{1}\right)$ \\
\hline 06 & $\left(\mathbf{T}_{5}=\mathbf{N}_{1}+\mathbf{G}_{2}\right)$ \\
\hline 07 & $\left(\mathbf{T}_{6}=\mathbf{N}_{2}+\mathbf{G}_{0}\right)$ \\
\hline 08 & $\left(\mathbf{T}_{7}=\mathbf{N}_{2}+\mathbf{G}_{1}\right)$ \\
\hline 09 & $\left(\mathbf{T}_{8}=\mathbf{N}_{2}+\mathbf{G}_{2}\right)$ \\
\hline
\end{tabular}

Treatment Combination

(@ 0\% N: P: K + 0\%.GYPSUM)

(@ 0\% N: P: K + 50\%.GYPSUM)

(@ 0\% N: P: K + 100\%GYPSUM)

(@50\%N: P: K+0\%GYPSUM)

(@50\% N: P: K+ 50\%GYPSUM)

(@50\%N: P: K+100\%GYPSUM)

(@100\%N: P: K+0\%GYPSUM)

(@100\%N: P: K+50\%GYPSUM)

(@100\%N: P: K+100\%GYPSUM)

Table.2 Soil physical parameters before sowing of groundnut

\begin{tabular}{llll}
\hline S. No. & Particular & Results & Methods
\end{tabular}

\begin{tabular}{|c|c|c|c|}
\hline 1. & Bulk density $\left(\mathrm{Mg} \mathrm{m}^{-3}\right)$ & 1.07 & (Black 1965) \\
\hline 2. & Particle density $\left(\mathrm{Mg} \mathrm{m}^{-3}\right)$ & 2.24 & (Black 1965) \\
\hline 3. & Soil texture (\%) Sand- 55\% & $0 \%, \mathrm{Cl}$ & Loam (Bouyoucos 1927) \\
\hline 4. & Soil colour 2.5 Y, 6/4 Light & & MunshellColour Chart \\
\hline 5. & Pore space $(\%)$ & 47.05 & (Black 1965) \\
\hline 6. & Water holding capacity (\%) & 76.67 & (Black 1965) \\
\hline
\end{tabular}

Table.3 Soil Chemical parameters before sowing of groundnut

S. No. Particular

1. Soil $\mathrm{pH}(1: 2)$

2. Soil EC (dS m $\left.{ }^{-1}\right)$

3. Organic Carbon (\%)

4. Available Nitrogen $\left(\mathrm{Kg} \mathrm{ha}^{-1}\right)$

5. Available Phosphorus (Kg ha ${ }^{-1}$ )

6. Available Potassium ( $\mathrm{Kg} \mathrm{ha}^{-1}$ )

7. Available Sulphur $\left(\mathrm{kg} \mathrm{ha}^{-1}\right)$

7. Available calcium (meq./100gm of soil)
Methods

Results

(Jackson, 1973)

7.32

(Wilcox, 1950)

0.610

Walkley and Black's method (1947)

(Subbaih and Asija, 1956)

236.58

(Olsen et al., 1950)

(Toth and Prince, 1949)

156.60

Chesnin and Yien (1950)

19.89

EDTA method 
Table.4 Interaction effect of different levels of N P K and Gypsum on Physico-chemical properties of Soil

\begin{tabular}{|c|c|c|c|c|c|c|}
\hline Treatments & $\begin{array}{l}\text { Bulk } \\
\text { density } \\
\left(\mathrm{g} \mathrm{cc}^{-1}\right) \\
\end{array}$ & $\begin{array}{l}\text { Particle } \\
\text { density } \\
\left(\mathrm{g} \mathrm{cc}^{-1}\right)\end{array}$ & $\begin{array}{l}\text { Pore } \\
\text { space } \\
(\%) \\
\end{array}$ & $\begin{array}{c}\text { pH 1:2 } \\
(\mathrm{W} / \mathrm{V})\end{array}$ & $\underset{1}{\mathbf{E}})$ & $\begin{array}{l}\text { Organic } \\
\text { carbon } \\
(\%)\end{array}$ \\
\hline $\mathrm{T}_{0}=\left(\mathrm{N}_{0}+\mathrm{G}_{0}\right)$ & 1.07 & 2.24 & 47.05 & 7.13 & 0.634 & 0.61 \\
\hline $\mathrm{T}_{1}=\left(\mathrm{N}_{0}+\mathrm{G}_{1}\right)$ & 1.02 & 2.25 & 48.90 & 7.13 & 0.629 & 0.61 \\
\hline $\mathrm{T}_{2}=\left(\mathrm{N}_{0}+\mathrm{G}_{2}\right)$ & 1.13 & 2.62 & 50.00 & 7.23 & 0.619 & 0.64 \\
\hline $\mathrm{T}_{3}=\left(\mathrm{N}_{1}+\mathrm{G}_{0}\right)$ & 1.09 & 2.51 & 49.02 & 7.07 & 0.614 & 0.68 \\
\hline $\mathrm{T}_{4}=\left(\mathrm{N}_{1}+\mathrm{G}_{1}\right)$ & 1.05 & 2.52 & 50.00 & 7.17 & 0.694 & 0.69 \\
\hline $\mathrm{T}_{5}=\left(\mathrm{N}_{1}+\mathrm{G}_{2}\right)$ & 1.18 & 2.73 & 50.98 & 7.37 & 0.612 & 0.82 \\
\hline $\mathrm{T}_{6}=\left(\mathrm{N}_{2}+\mathrm{G}_{0}\right)$ & 1.07 & 2.41 & 48.03 & 7.33 & 0.610 & 0.74 \\
\hline $\mathrm{T}_{7}=\left(\mathrm{N}_{2}+\mathrm{G}_{1}\right)$ & 1.04 & 2.47 & 49.98 & 7.3 & 0.714 & 0.72 \\
\hline $\mathrm{T}_{8}=\left(\mathrm{N}_{2}+\mathrm{G}_{2}\right)$ & 1.03 & 2.34 & 49.17 & 7.27 & 0.614 & 0.79 \\
\hline F-test & $S$ & $S$ & $S$ & NS & NS & NS \\
\hline S. Em. $( \pm)$ & 0.020 & 0.019 & 0.557 & 0.213 & 0.054 & 0.027 \\
\hline C.D. at $5 \%$ & 0.042 & 0.041 & 1.180 & 0.452 & 0.115 & 0.057 \\
\hline
\end{tabular}

Table.5 Interaction effect of different levels of N P K and Gypsum on Physico-chemical properties of Soil

\begin{tabular}{lccccc}
\hline Treatments & $\begin{array}{c}\text { Nitrogen } \\
\left(\text { kg ha }^{-1}\right)\end{array}$ & $\begin{array}{c}\text { Phosphorus } \\
\left(\text { kg ha }^{-1}\right)\end{array}$ & $\begin{array}{c}\text { Potassium } \\
\left(\text { kgha }^{-1}\right)\end{array}$ & $\begin{array}{c}\text { Sulphur } \\
\left(\text { kgha }^{-1}\right)\end{array}$ & Calcium \\
\hline$\left(\mathrm{T}_{0}=\mathrm{N}_{0}+\mathrm{G}_{0}\right)$ & 236.57 & 19.51 & 127.24 & 19.89 & 1.06 \\
$\left(\mathrm{~T}_{1}=\mathrm{N}_{0}+\mathrm{G}_{1}\right)$ & 244.95 & 19.81 & 142.01 & 19.89 & 2.67 \\
$\left(\mathrm{~T}_{2}=\mathrm{N}_{0}+\mathrm{G}_{2}\right)$ & 254.38 & 20.41 & 153.43 & 20.88 & 2.73 \\
$\left(\mathrm{~T}_{3}=\mathrm{N}_{1}+\mathrm{G}_{0}\right)$ & 255.43 & 21.01 & 157.18 & 21.55 & 2.75 \\
$\left(\mathrm{~T}_{4}=\mathrm{N}_{1}+\mathrm{G}_{1}\right)$ & 261.72 & 22.58 & 172.14 & 22.46 & 2.83 \\
$\left(\mathrm{~T}_{5}=\mathrm{N}_{1}+\mathrm{G}_{2}\right)$ & 268.01 & 23.4 & 183.44 & 23.49 & 2.85 \\
$\left(\mathrm{~T}_{6}=\mathrm{N}_{2}+\mathrm{G}_{0}\right)$ & 278.72 & 23.7 & 202.63 & 27.28 & 2.92 \\
$\left(\mathrm{~T}_{7}=\mathrm{N}_{2}+\mathrm{G}_{1}\right)$ & 275.34 & 25.2 & 213.31 & 29.78 & 3.13 \\
$\left(\mathrm{~T}_{8}=\mathrm{N}_{2}+\mathrm{G}_{2}\right)$ & 286.87 & 27 & 220.8 & 32.44 & 3.31 \\
F-test & $\mathrm{S}$ & $\mathrm{S}$ & $\mathrm{NS}$ & $\mathrm{S}$ & $\mathrm{S}$ \\
S. Em. $( \pm)$ & 0.923 & 0.054 & 5.598 & 0.722 & 0.047 \\
C.D. at $5 \%$ & 1.957 & 0.115 & 11.868 & 1.530 & 0.099 \\
\hline
\end{tabular}


Fig.1 Effect of different levels of N P K and gypsum on their interaction on N P K and of groundnut

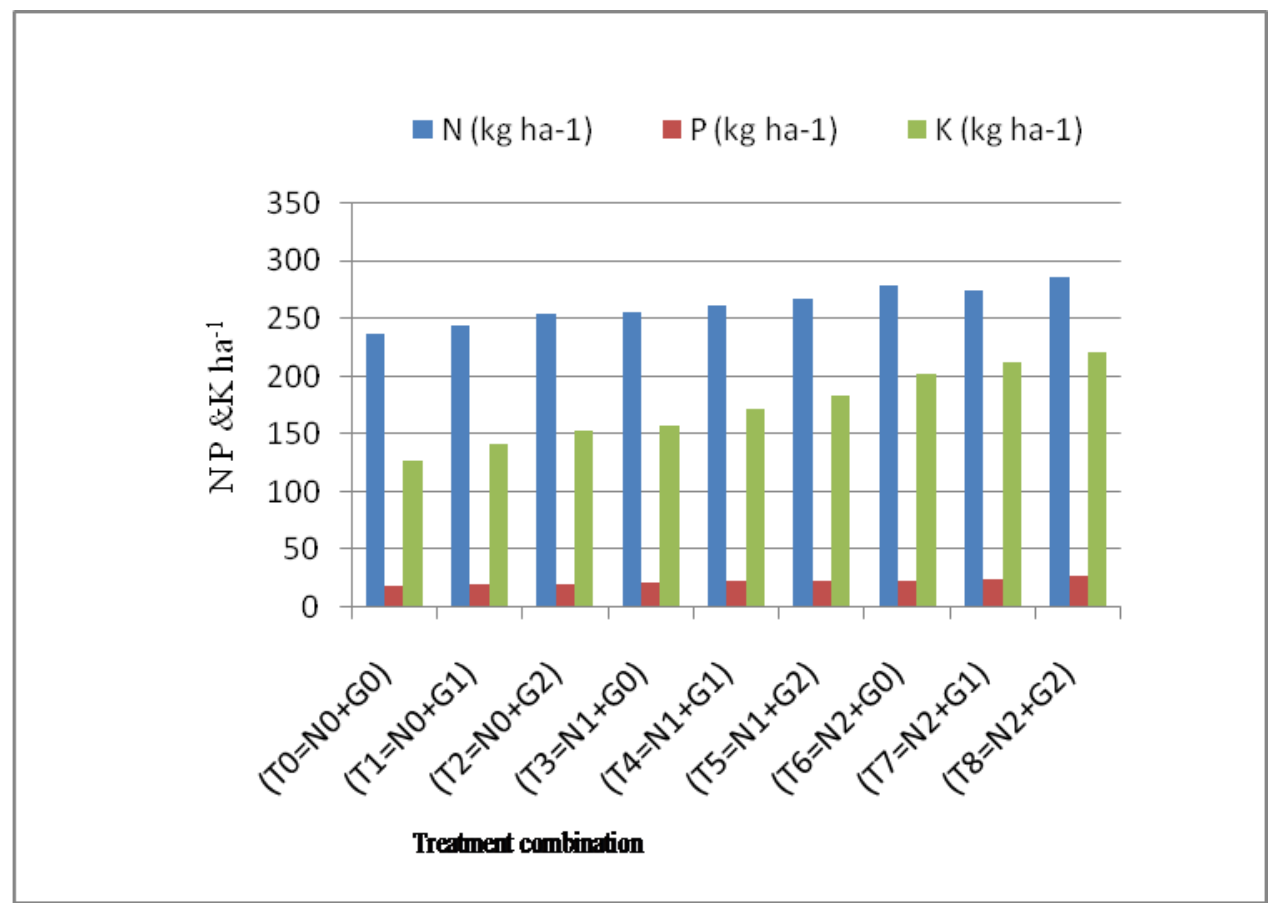

Fig.2 Effect of different levels of N P K and gypsum on their interaction on sulphur and calcium of groundnut

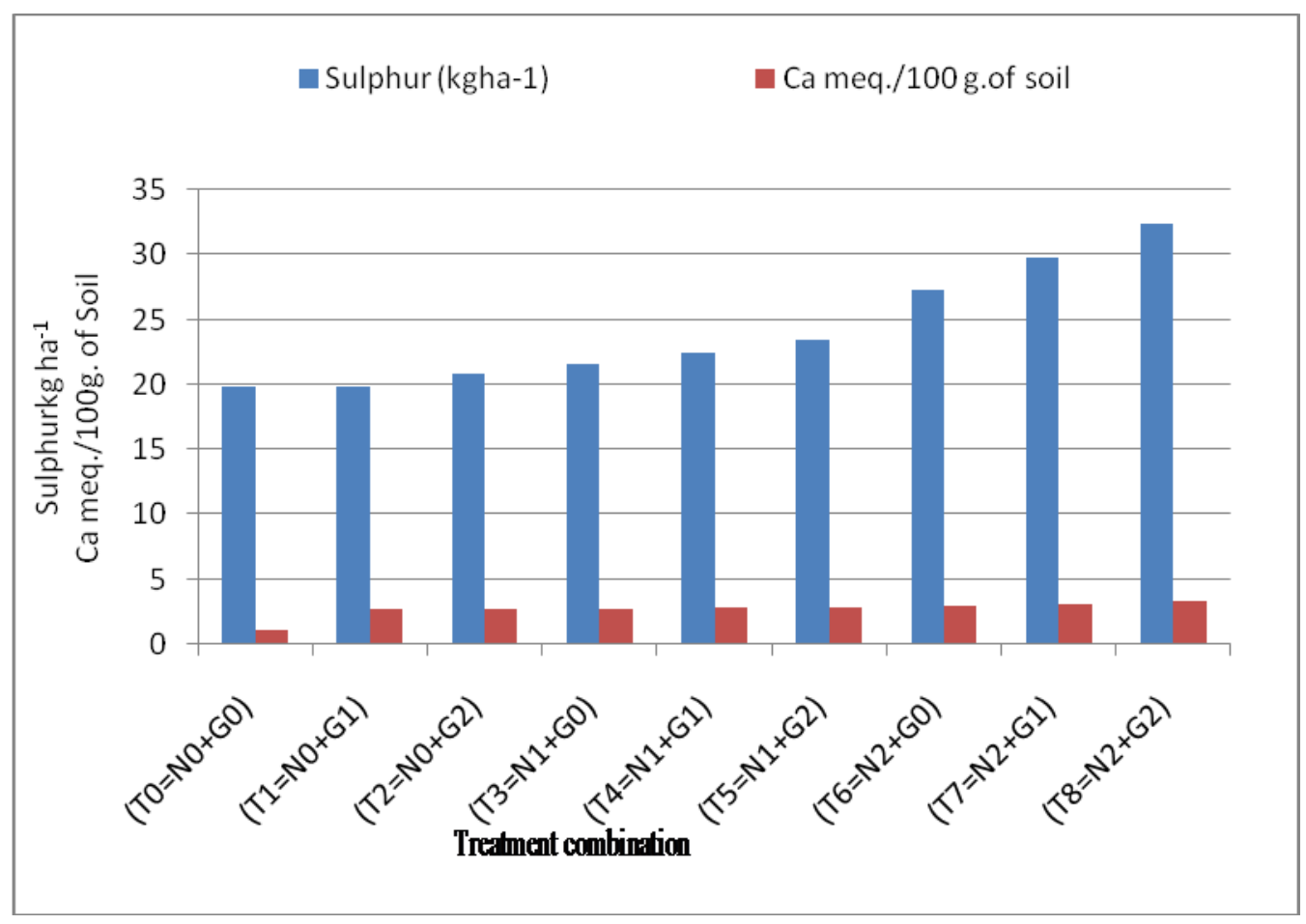


Fig.3 Effect of different levels of N P K and gypsum on their interaction on $\mathrm{pH}$ and $\mathrm{EC}$ of groundnut

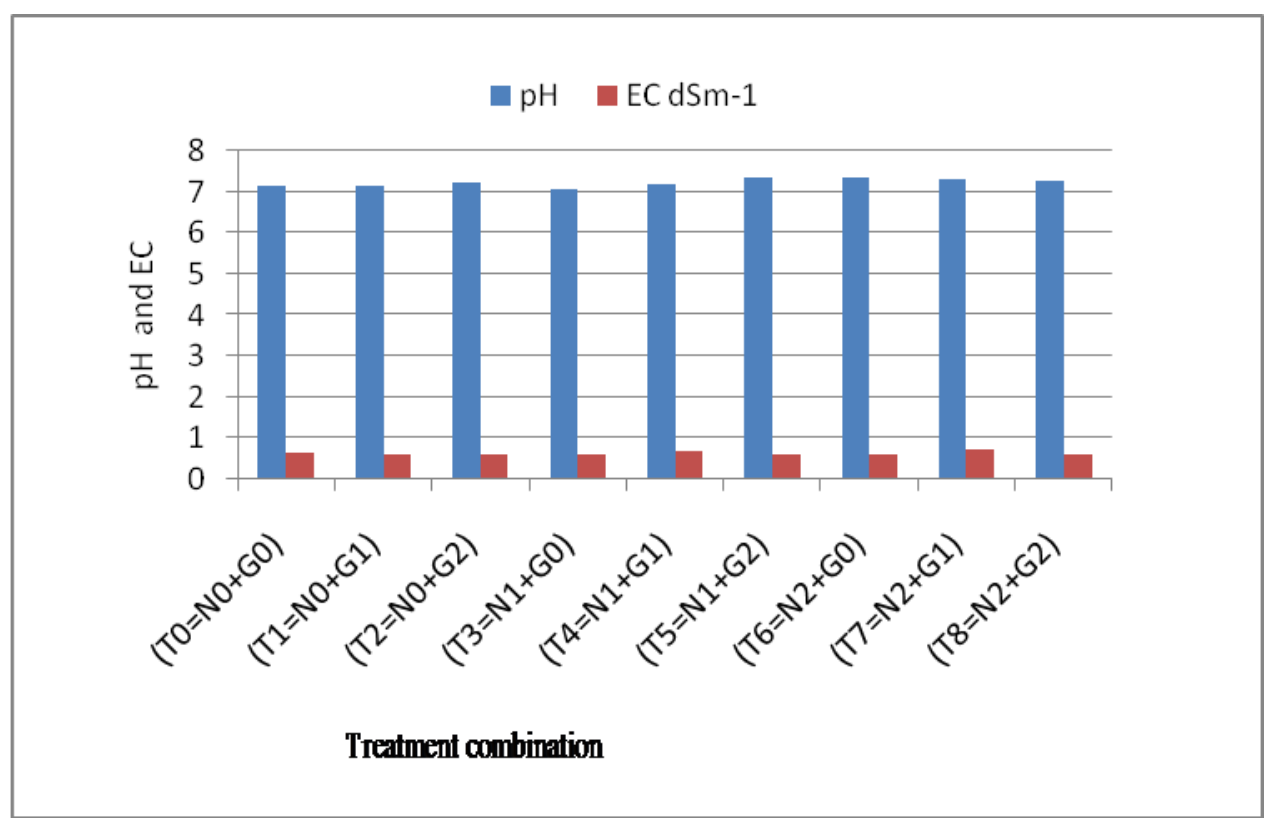

The statistical analysis of potassium data indicates that there was significant difference in potassium interaction between $\mathrm{N} \mathrm{P} \mathrm{K}$ and Gypsum. In case of sulphur the maximum sulphur 32.44 was recorded with (N2G2) treatment combination followed by 29.78 with (N2G1) treatment combination whereas the minimum 19.89 sulphur was recorded with control (N0G0) treatment. The statistical analysis of sulphur data indicates that there was significant difference in sulphur interaction between N P K and Gypsum. The maximum calcium 3.31 was recorded with (N2G2) treatment combination followed by 3.13 with (N2G2) treatment combination whereas the minimum 1.06 calcium was recorded with control (NOG0) treatment. The statistical analysis of calcium data indicates that there was a significant difference in calcium interaction between $\mathrm{N} P \mathrm{~K}$ and Gypsum.

In conclusion, it showed the best result on growth and yield of groundnut (Arachis hypogeae L.) in comparison to other treatment combination. It was recorded from the application of chemical fertilizers in treatment T8 [(@100\% N P K + 100\% Gypsum)] was found to be the best treatment gave highest benefit of 52125 with highest cost benefit ratio 1:2.66 for Groundnut, it could be recommended for profitable production of Groundnut (Arachish hypogeae L.) var. Jyoti and treatment is good for soil physical and chemical properties. Effect of different levels of N P K and Gypsum is better for soil health and Groundnut production.

\section{References}

Bouyoucous, G.J. 1927. The hydrometer as a new method for the mechanical analysis of soils. Soil Sci., 23: 393-395.

Black, C.A. 1965. Methods of soil analysis vol.2, Am. Soc, Agron., madison, Wisconsin, U.S.A.

Chikowo, R. 1998. Soil fertility management option for improved groundnut production in the small holder section. M. Phil thesis, University of Zimbabwe. 
Chesnin, L. and C.H. Yien. 1950. Turbidimetric determination of available sulphate, Soil. Sci. Amer. Proc., 15: 149-151.

Cox, F.R., Adams, F. and Tucker, B.B. 1982. Liming, fertilization and mineral nutrition. In. Peanut Science and Technology (Eds. Pattec, H. and Young, C.). American Peanut Res. Edu. Soc., pp. $138-59$.

DOAC. 2012. Directorate of Economics and Statistics, Directorate of Agriculture and Cooperation, Government of India, New Delhi.

Jackson, M.L. 1958. Soil chemical analysis, Second edition Indian Reprint, prentice hall of India, New Delhi, PP 498.

Olsen, S.R., Cole, C.V., Watnahe, F.S. and Dean, L.A. 1954. Estimation of available phosphorus in soils by extraction with sodium bicarbonate U.S. Deptt. Agr.Circ., pp 939.

Singh, A.L. 2004. Mineral nutrient requirement, their disorders and remedies in groundnut. Groundnut
Research in India, National Research Centre for Groundnut, Junagadh, India. pp. 137-159.

Subbaih, B.V., and Asija, C.L. 1956. A rapid proceducre for the estimation of available nitrogen in soils. Curr. Sci., 25: pp 256-260.

Sathya Priya, R., Chinnusamy, C., Manicaksundaram, P., Babu, C. 2013. A review on weed management in groundnut (Arachishypogaea L.). Int. J. Agri. Sci. Res., 3: 163-172.

Varghese, N. 2011. Changing directions of groundnut trade in India: The WTO effect. Int. Conference on Appl. Economics, Pp. 731.

Walkley, A. and Black, I.A. 1947. Critical examination of rapid method for determining organic carbon in soils, effect of variance in digestion conditions and of inorganic soil constituents. Soil Sci., pp. 632:251.

Wilcox, L.V. 1950. Electrical conductivity, Amer Water Works Assoc. J., 42: pp $775-776$.

\section{How to cite this article:}

Murli Dhar Bairagi, Arun Alfred David, Tarence Thomas, and Prakash Chand Gurjar. 2017. Effect of Different Level of N P K and Gypsum on Soil Properties and Yield of Groundnut (Arachis hypogaea L.) var. Jyoti. Int.J.Curr.Microbiol.App.Sci. 6(6): 984-991. doi: https://doi.org/10.20546/ijcmas.2017.606.115 